\title{
UNIVERSITYOF
}

FORWARD

THINKING

WESTMINSTER用

WestminsterResearch

http://www.westminster.ac.uk/westminsterresearch

PSM in Italy: Troubled RAI in a Troubled Country

D'Arma, A.

D'Arma, A. (2019) PSM in Italy: Troubled RAI in a Troubled Country, in: Połońska, E. and Beckett, C. (ed.) Public Service Broadcasting and Media Systems in Troubled European Democracies, Palgrave Macmillan, pp. 111-128 , 2019, reproduced with permission of Palgrave Macmillan.

This extract is taken from the author's original manuscript and has not been edited. The definitive, published, version of record is available here:

https://www.palgrave.com/gp/book/9783030027094

The WestminsterResearch online digital archive at the University of Westminster aims to make the research output of the University available to a wider audience. Copyright and Moral Rights remain with the authors and/or copyright owners.

Whilst further distribution of specific materials from within this archive is forbidden, you may freely distribute the URL of WestminsterResearch: (http://westminsterresearch.wmin.ac.uk/)).

In case of abuse or copyright appearing without permission e-mail repository@westminster.ac.uk 


\section{PSM in Italy: Troubled RAI in a troubled country}

\section{Introduction}

In many ways, public service broadcasting in Italy can be considered as a successstory. RAI, the country's public service broadcasting organisation established after the end of World War II and operating as a state monopoly until the mid-1970, continues to this day to occupy a central place in the national media landscape. In 2016 its three 'legacy' television channels (RAI1, RAI2, and RAI3) commanded 30\% of all television viewing, in spite of growing commercial competition over the years. RAl's suite of specialised channels (including news, children's, cultural and sports channels) added a further $7 \%$, bringing RAl's total viewing share to $37 \%$. No other European public service broadcasting organisation commanded as high a share of the national television viewing as RAI. Mediaset, RAl's main commercial rival, trailed behind with a share of $32 \%$. While television consumption has been (slowly) decreasing in recent years, as the time spent by people online keeps growing, television remains by far the most popular medium in Italy. It was estimated that Italians watched over 4 hours of television on the average day in 2016 (Ofcom 2017). Television's reach is unmatched, and it remains especially high among the older generations (which make up a significant proportion of an aging country). RAl is also the biggest player in the radio sector, where it accounts for around a quarter of total industry revenue (Agcom 2017). Its radio services are widely praised for their highquality and public service orientation. As the country's 'main cultural institution', RAI makes a major contribution in supporting the national audioviosual industry. In its more recent annual report, RAI claimed that in 2016 its overall investments in local TV drama and comedy had represented over $70 \%$ of total investments in the sector (RAI 2017: 7). RAI had produced the 20 most popular TV fictional programmes shown in that year. Last but not least, RAI remains the country's largest journalistic organisation, employing nearly 2,000 journalists, a number four times as high the number of journalists working for Mediaset and twice the number of journalists at the country's largest newspaper publisher, Gruppo Editoriale L'Espresso. RAl's extensive and costly network of regional newsrooms, with a workforce of around 700 journalists, plays a fundamental role in ensuring coverage of local events (all the more so at a time when local news outlets, both print and broadcast, are facing existential challenges).

And yet, these contributions notwithstanding, RAl is often portrayed as a mammoth organisation falling prey to political patronage, weakened by both commercial and political pressures, and ultimately failing to fulfil its public service remit in key areas such as the provision of distinctive and innovative television programmes across all genres (D'Arma, 2015). Widely perceived as a highly politicised organisation and criticised for its excesses of commercialism in its entertainment-oriented fare, RAI has historically enjoyed a low level of support among the general public (notwithstanding the high share of viewing that, as seen, its main channels still command). 
These perceived failings of RAl as a public service institution have long made the political case for intervening in its organisation, funding and system of governance a compelling and seemingly pressing one. In post-1994 Berlusconi's Italia, 'reforming RAl' was high in the media policy agenda (Hibberd, 2004; Hanretty, 2009; D'Arma, 2009). And yet, despite repeated attempts at reforms and persisting calls for privatisation across the political spectrum, the key pillars of RAl's institutional design were not altered during the ventennio Berlusconiano (as the twenty-year period from 1994-2013 dominated politically by Silvio Berlusconi is often referred to). Throughout this time, RAl continued to operate as a state-owned company funded by the licence fee (an hypothecated tax levied on all television households) supplemented by proceeds from the sale of advertising. For the worse or for the better, then, during this period a comprehensive reform of RAI in Italy remained an elusive target, attesting to the limited capacity for regulatory change in Italy in areas like public service broadcasting where entrenched political interests are at stake.

The main aim of this chapter is to provide an account of the most significant developments concerning public service broadcasting in Italy after 2013, a period during which the country continued to experience a major economic downturn as well as undergoing significant political change. The latter included the growth of populist and anti-establishment political actors, exploiting popular discontent with mainstream parties, seen as corrupted and incapable to fix the country's economic problems (see Tarchi, 2015). Most notably this period saw the rise of the Five Stars Movement, a protest movement grown out of a blog run since 2005 by comedian and activist Beppe Grillo. The Five Stars Movement established itself as Italy's second-biggest political party in the national elections of 2013 and has remained at the forefront of the Italian political scene ever since then. The other main political novelty of these years was the rise of Matteo Renzi, from the centre-left Democratic Party. At 39 years of age, Renzi became in February 2014 Italy's youngest ever Prime Minister, adopting a populist and highly personalised (and divisive) style of leadership (an absolute novelty for his political camp). Renzi resigned in late 2016 after losing a major constitutional referendum, albeit remaining at the helm of his party.

As it will be discussed in this chapter, under the reform-driven government of Matteo Renzi (2014-2016), both RAl's funding model and its system of governance underwent major changes, although neither of these interventions were seen as adequate in providing a solution to the underlying problems they were supposedly meant to fix, namely insulating RAI from party political pressure and putting it on a more solid financial footing. More generally, as it will be discussed in the last two sections of the chapter, during the period under examination political factors have continued to constrain RAl's ability to implement much-needed internal reorganisations (notably, of its news operations) and take long-term strategic decisions enabling RAl to face up to the digital challenge. Before turning to a consideration of these developments, the next section briefly looks at the impact that the economic crisis has had on the Italian media sector generally and on RAI in particular. 


\section{A shrinking media market}

The effects of the global financial crisis of 2008 began to be felt on the Italian media system starting from 2010, leading to a shrinking of the sector in the years since. Like all the other 'legacy' players, RAI too, given its reliance on advertising revenues, has been hit hard by the economic downturn, whose effects have been compounded by the shift of financial resources away from traditional media and towards the Internet (albeit this shift has been less pronounced in Italy than elsewhere). According to figures provided by the Italian communications regulator (Agcom, 2016), the commercial revenues of the entire national media sector (both from the sale of advertising and direct consumer payment) fell by $17 \%$ from 2010 to 2015 , down to $€ 14.0$ billion from $€ 16.8$ million. Advertising revenues in particular, after having grown steadily until 2009, fell by 22\%, or nearly a quarter, between 2010 and 2015 (from $€ 8.8$ to $€ 6.9$ billion) (see Figure 1 ).

Figure 1. Media industry revenues in Italy, 2010 vs. 2015 (in million €)

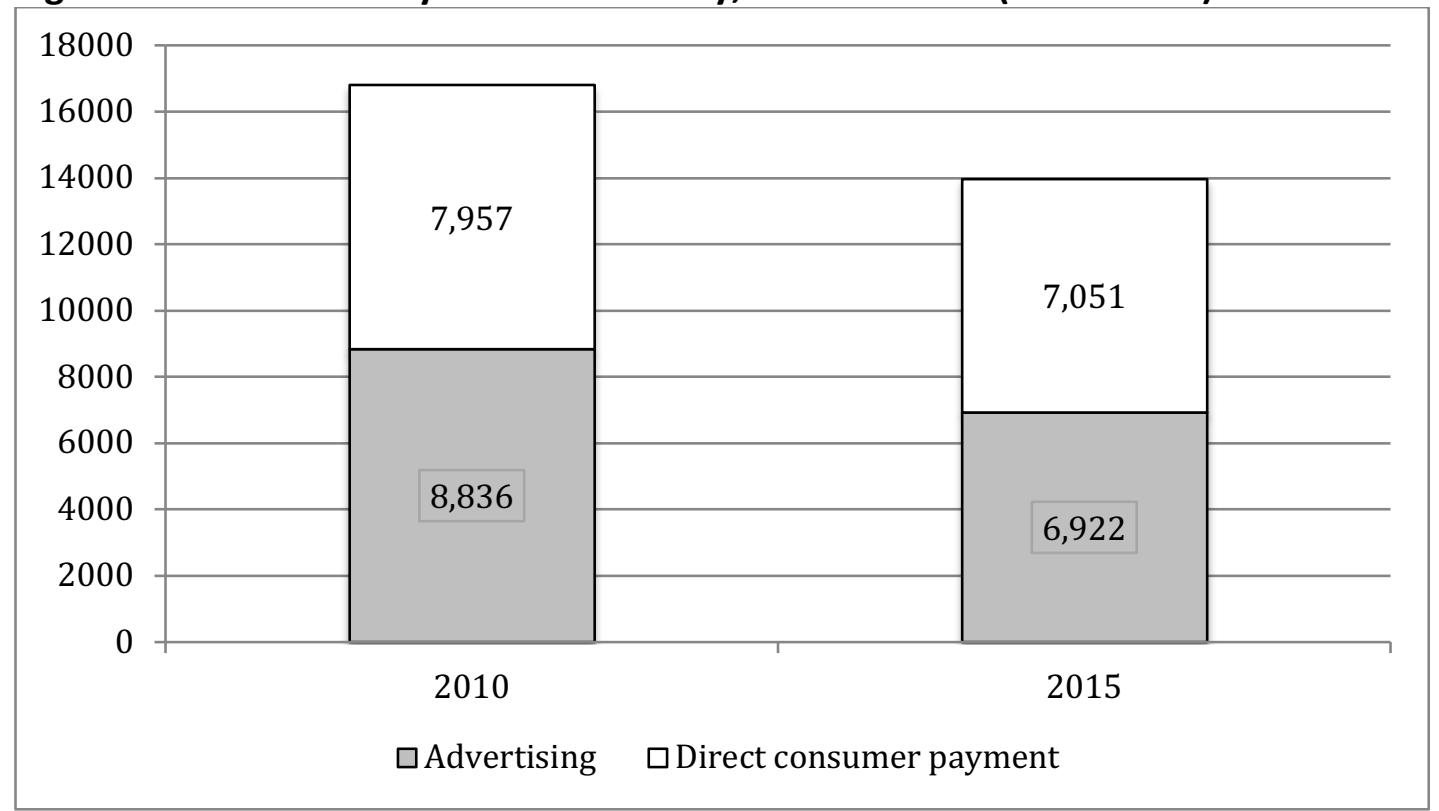

Source: AGCOM 2016

Notes: Include commercial revenues in the television, radio, newspaper, magazine and Internet sectors.

Among traditional media, the TV sector withstood the crisis better than newspapers during this period, but its revenues also decreased steadily until 2016. In 2106, for the first time in several years, there was a reversal of the downward trend, even though industry revenues remained below their 2010 levels (see Figure 2).

Figure 2: TV industry revenues by type, 2010-2016 (in million $€$ ) 


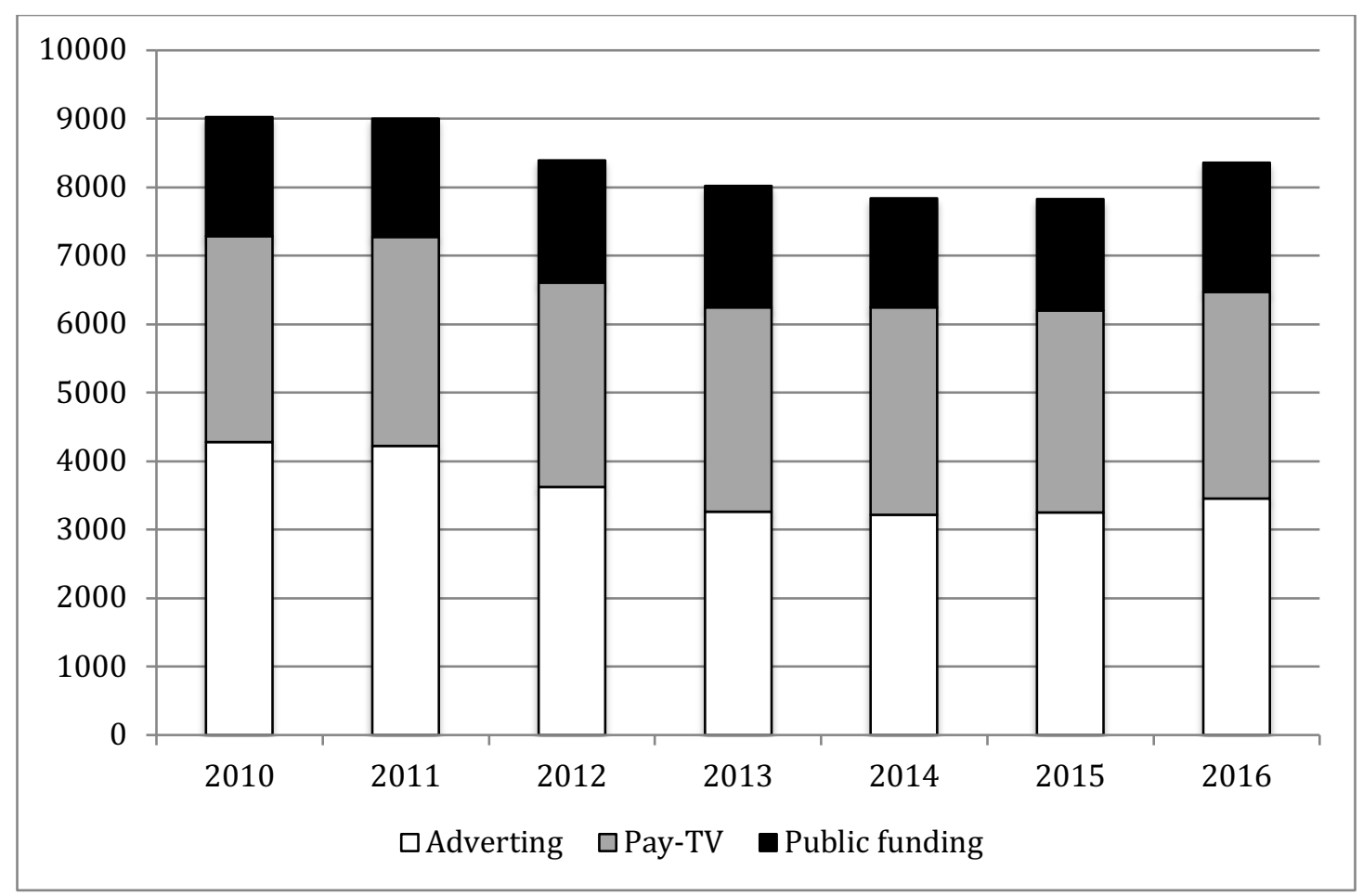

Source: Author's elaboration on AGCOM 2016 and 2017

As shown in Table 1 below, between 2010 and 2016 the TV sector dropped by 7\% in overall industry revenue (comprising revenues from advertising, pay-TV and public funding) - down to €8.4 billion in 2016 from $€ 9.0$ billion in 2010. Advertising revenue declined more sharply than revenue from pay-TV, but remained the largest revenue stream, accounting in 2016 for $41 \%$ of total television revenue.

Table 1: TV industry revenues by type, 2010-2016 (in million €)

\begin{tabular}{lccccccc|r|r|}
\hline & $\mathbf{2 0 1 0}$ & $\mathbf{2 0 1 1}$ & $\mathbf{2 0 1 2}$ & $\mathbf{2 0 1 3}$ & $\mathbf{2 0 1 4}$ & $\mathbf{2 0 1 5}$ & $\mathbf{2 0 1 6}$ & $\begin{array}{c}\Delta \\
\mathbf{2 0 1 6 / 1 0} \\
\text { (\%) }\end{array}$ & $\begin{array}{c}\text { Market } \\
\text { share } \\
\mathbf{2 0 1 6}\end{array}$ \\
\hline Advertising & 4,282 & 4,221 & 3,621 & 3,266 & 3,220 & 3,249 & 3,453 & -19.7 & 41.3 \\
Pay TV & 3,006 & 3,051 & 2,990 & 2,984 & 3,023 & 2,952 & 3,018 & -0.4 & 36.1 \\
Public funding & 1,736 & 1,732 & 1,776 & 1,774 & 1,600 & 1,629 & 1,889 & +8.8 & 22.6 \\
\hline Total & 9,025 & 9,004 & 8,388 & 8,024 & 7,844 & 7,830 & 8,360 & -6.8 & 100 \\
\hline
\end{tabular}

Source: Author's elaboration on AGCOM 2016 and 2017

Public funding, the near totality of which is income derived from licence fee payments in favour of RAl, accounted for $22 \%$ of total industry revenue in 2016 (see Table 1 above). As it will be discussed in the next section, the noticeable increase recorded in 2016 (from $€ 1,629$ million in 2015 to $€ 1,889$ million), after years of stagnation, was due to a change in the method for collecting the licence fee (now linked to the electricity bill), leading to a drastic reduction in the rate of licence fee evasion (from over $25 \%$ to just $5 \%$ ). In parallel to linking the licence fee to the electricity bill, the government also took the decision to reduce the per-household fee from $€ 113.5$ in 2015 to $€ 90$ in 2017. At the time this was written, RAl's 2017 financial results had not yet been released, but it was expected that the drastic reduction in the unit fee would almost entirely neutralise the positive effects of 
extra income deriving from reduced evasion and thus that RAI's licence fee revenues for 2017 would return to their pre-2016 levels.

Advertising, RAl's other main source of revenue, almost halved in a 10 -year period: from $€ 1,137$ million in 2007 to $€ 698$ million in 2016 (see Figure 3 below). Advertising revenues now accounts for only $25 \%$ of RAl's total revenue (down from $40 \%$ ten years ago). However, RAI still depends on this source of revenue to cover its running costs. Thus, commercial considerations continue to have a significant bearing on RAl's programming decisions. As it will be discussed in the next section, by increasing commercial pressure, reliance on advertising is considered to be the root cause of the historic charge levelled against RAI to chase audience ratings at the neglect of its public service obligations.

Figure 3: RAl's revenue breakdown (2007-2016)

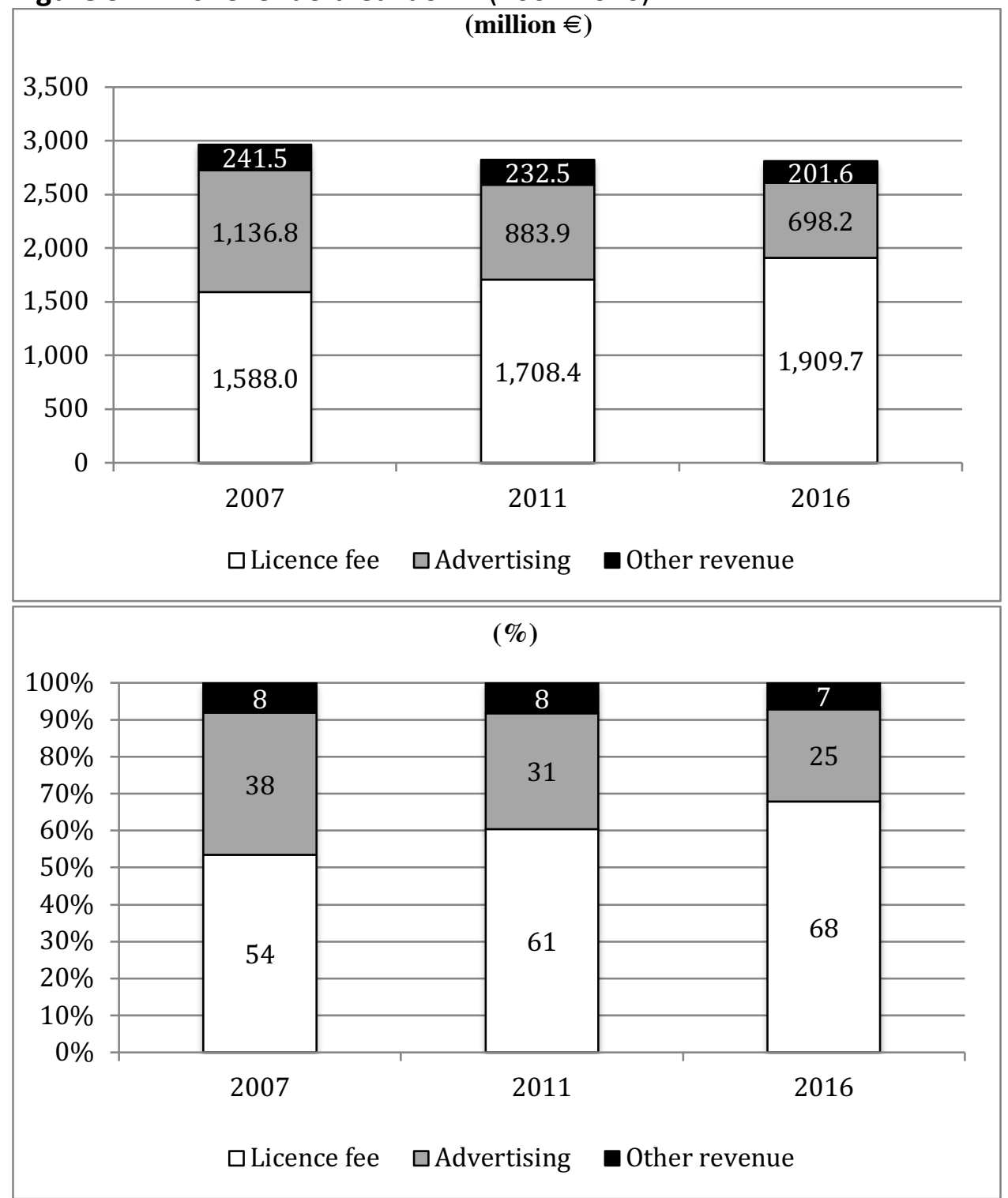

Source: Author's elaboration on RAl annual reports

Note: The licence fee figures here do not match with the figures on 'public funding' reported in Figure 2 and Table 1 (source: Agcom). The reason for this is that Agcom's figures exclude the portion of 
licence fee income that according to Agcom's estimates is allocated to finance RAl's radio services (while they include public subsidies in favour of local television channels).

The dramatic fall in RAl's advertising revenue in the last 10 years reflects the general trend in the national advertising market. However, RAl's main channels have also lost commercial appeal relative to other channels. Though remaining among the most watched channels, they have lost viewers in recent years, especially among younger people. Advertisers have shifted part of their budgets online or on the plethora of TV channels available on digital terrestrial satellite platforms. In response to this challenging market environment, RAI has adopted an aggressive policy of discounts, which has angered commercial broadcasters. Finally, it is important to note how the vast majority of RAl's advertising revenues are still accounted for by its three legacy channels, and in particular by RAI1, RAl's flagship channel. By contrast, RAl's digital channels and its online activities still contribute very little to RAl's commercial income. In 2016, RAl made a mere $€ 8.5$ million in online advertising revenue (or about $1 \%$ of RAl's total adverting revenues!), reflecting its underwhelming performance online (more on which below)

\section{Reforming RAl under Renzi's government (2014-2016)}

As mentioned in the introduction of this chapter, reforming RAI was one of the many items in the reformist agenda pursued by Matteo Renzi's centre-left government (2014-2016). As it will be discussed in this section, both the system for collecting RAl's licence fee and its governance underwent major changes during 2015, more than 10 years after the last reform under the Berlusconi government. Before recounting Renzi's recent initiatives, however, it is important to see this latest attempt at reforming RAI in a historical perspective.

\section{A brief history of post-1994 reform attempts}

As its Southern European counterparts, RAI has long faced criticism for its bias towards the government of the day and for chasing ratings rather than quality in its programming (e.g., Mazzoleni and Vigevani, 2005; Padovani and Tracey, 2003). These two departures from the normative ideals of public service broadcasting (political independence and non-commercialism) have different origins and explanations.

In the comparative literature, RAI is often taken as a paradigmatic case of a highly (party) politicised public service broadcaster (see, e.g., Blumler 1992; Humphreys 1996; Hanretty 2009). Political interference in the management of RAI has arguably been a constant feature of RAl's over sixty-year-long history, although the forms in which this phenomenon has manifested itself have changed considerably over time from what has been described as 'a lengthy post-war period of majoritarianism, oneparty dominance' to 'a state of multi-party politicisation lasting from the late 1970s through the 1980s' (Humphreys 1996, 153-54); and from a period of more majoritarian-style dominance in post-1994 Italy, in parallel with the shift towards a 
more competitive political system in the early 1990s, to the return to more party politicised boards in accordance to the rules of proportional representation after a further legislative change of RAl's governance in 2004 (see below). Scholars have argued that RAl's deficit of political independence throughout its history is deeply rooted in the country's enduring political culture, and in particular in a weak tradition of journalistic professionalism and autonomy (see, e.g., Mancini 2009). Politicians have always regarded news media, and public broadcasting in particular, as a central site for the exercise of political power and journalists have been all too prone to political power.

RAl's commercialism, on the other hand, has been explained on account of RAl's reliance on income from advertising. More specifically, it is seen as an enduring legacy of the 'savage deregulation' of the 1980s when RAl was abruptly forced to enter into fierce competition for audience and adverting revenue with the new private channels, which were left completely unregulated (see, e.g., Richeri, 1990). RAl's programming strategies were deeply transformed during those years. A commercial logic, so the argument goes, became increasingly pervasive within the organisation and weakened RAl's public service ethos.

In the early 1990s, thus, RAI provided one of the most striking examples in Western Europe of a public service broadcaster struggling amid old political pressures (arising from a deeply ingrained culture of party-political interference over all state-owned bodies and weak journalistic autonomy) and new market imperatives (in the context of fierce competition with the expanding private sector). RAl's vulnerability to both political and commercial pressure meant that calls for its reform and even for its privatisation were recurring during this period. And yet, the highly politicised nature of the issue explains why until Matteo Renzi came to power in 2014 (that is, during a twenty-year period) the only regulatory change (whose impact was limited in scope) was the so-called Gasparri Law of 2004 (from the name of the proponent minister of the then Berlusconi government). The Gasparri Law established new rules for appointing RAl's board (Consiglio di Amminstrazione). Its members were increased from five to nine and power of appointment, which from 1993 had rested upon the Speakers of the two Houses of Parliament, the two most senior institutional figures after the President of the Republic, and thus 'theoretically above party politics' (Hibberd 2001, 242), was handed back to a highly politicised parliamentary committee overseeing RAl, as it had been the case from the mid-1970s until 1993. The Gasparri law also gave the government, RAl's main shareholder, power over the appointment of two members, including the chairman. By transferring power of appointment to Parliament and (controversially) government, the Gasparri law deviated strikingly from the set of measures that legal experts concurred would be needed to endow RAI with greater legal protection against political interference. These legal prescriptions included the involvement of actors outside 'institutional' politics in the appointment of the members of the RAI board (e.g., representatives of civil society, RAl's workforce, and academia) and restrictions on the possibility to serve as board member for those who have held elected political posts. 
Besides introducing new appointment procedure for RAl's board, the Gasparri Law, even more controversially, provided for a badly-conceived, much-criticised, but eventually never-implemented plan to list RAI on the stock exchange - a plan that ultimately envisaged RAl's full privatisation. The stated objective was to insulate RAI from party-political interference. No consideration, however, was given to how to reconcile the public service remit with shareholders' profit motive.

Shortly after returning to power in 2006, the centre-left government submitted a bill to Parliament taking on board several of the measures recommended by legal experts, including: the establishment of a Fondazione (Trust) to which RAl's shares would be transferred (to create a buffer between RAl and the government - RAl is a private-law limited company whose shares are held by the government); the extension of the term length for board members, stricter incompatibility rules, and the involvement of civil society in the appointments (Spada 2007; Padovani 2010). However, the bill did not make its way through Parliament before the fall of the executive in 2008, mid-way through the legislature, due to conflicts within the centre-left coalition.

\section{RAl's new governance: 'Keep the political parties out of RAl'?}

From 2008 until 2014, in the context of the economic crisis plaguing the country and amidst political uncertainty, the reform of RAI went pretty much off the radar. So much so that when in 2012 the three-year service contract between RAl and the Italian government expired its renewal was delayed in the general indifference. Upon forming its cabinet in early 2014, Matteo Renzi, the young and reform-driven leader of centre-left Democratic Party, however, pledged to make RAl more competitive in the marketplace and less vulnerable to political interference, with the slogan 'fuori i partiti dalla RAl' ('keep the political parties out of RAl'). The reform of RAI was thus, once again, put back on the political agenda.

Renzi's push to reform RAl boiled down initially to a change to the (much-criticised) procedures for appointing the RAl board established by the Gasparri law in 2004. A government bill submitted in the spring of 2015 was sealed into the statute book in December 2015. The new rules reduced the number of board members from nine to five and also established that RAl's director-general ('managing director' under the new rules) would be appointed by government and be given much wider powers visà-vis RAl's board. The board would in future comprise of two members elected by each house of the Parliament; two members appointed by government; and a member chosen by RAl employees. These changes might have gone some way towards achieving one of Renzi's two stated goals - that is, giving RAl a corporate makeover and make it a less bureaucratic organisation by strengthening the powers of the managing director. Commentators, however, agreed that the bill did not go far enough on its stated intention to severe the ties between RAl and politics. While it introduced incompatibility rules for those having served as high government officials, it provided controversially for the empowered figure of the managing director to be a government appointee. 
The other regulatory initiative of the Renzi government was to link the RAl licence fee payment to the electricity bill starting from 2016, in a bid to reduce rampant evasion. At the time, it was estimated that more than one in four Italian TV households was not paying licence fee and RAl claimed that evasion was subtracting $€ 600$ million from its annual budget. The introduction of the new collection method proved to be very effective in the fight against evasion: between 2015 and 2016, the number of households that paid the licence fee went from 16.5 to 22 million (with the rate of evasion now estimated to be at just 5\%). However, the positive impact on RAl's income was diluted by the contextual decision of the Renzi government to drastically reduce the unit fee from $€ 113.5$ to $€ 100$ in 2016 and then further down to $€ 90$ in 2017. Under the arrangements put in place by the government, the State would also keep a share of the extra income recovered from the evasion (33\% in 2016) and allocate it to local television channels and newspaper publishers. As seen in the previous section, despite the reduction of the fee to $€ 100$, RAl's licence fee income grew significantly in 2016 (an increase of Euro 272 million or $+16.6 \%$ compared to 2015). However, with the further reduction of the fee to $€ 90$ in 2017 (and the share of the extra-income to be kept by the State to be raised to $50 \%$ ), it was estimated that almost all the benefits of the introduction of the 'fee in the electricity bill' would be neutralised.

To sum up, Renzi was driven by the commendable aim to fight evasion of the licence fee payment on grounds of fairness and equality. His decision, contextually to the introduction of the new method of collection, to drastically reduce the perhousehold fee, under the slogan tutti pagano, tutti pagano di meno ('everyone pays, everyone pays less') was clearly a move designed to appease voters (the licence fee is often described as Italians' most despised tax). Ultimately, though, this was a missed opportunity to create the enabling financial conditions for RAl to better fulfil its public service remit, by increasing its level of public funding and reducing its reliance on advertising revenue. At $€ 90$ per-household, the licence fee in Italy is by far the lowest among the larger Western European countries (it is less than half the amount paid by German households). This is a hard fact that goes more often than not unnoticed the national political debate on public service broadcasting.

\section{RAl and politics under Renzi}

It is fair to say that the rise of Renzi to the centre of the national political scene did not mark a clear break with old practices and patterns of political behaviour in relation to public service broadcasting. Upon coming to power, Renzi pledged that he would keep politics out of RAl, but his first initiative appeared to betray the stated intentions. In the run up to regional elections of June 2014, his new government took abruptly the decision to levy $€ 150$ million against RAl's licence fee income for 2014 in order to help fund tax cuts for low-income earners. This was the latest in a series of historical instances of politicians meddling with RAl's funding. Renzi was criticised for what was seen as a populist electoral move in a bid to endear 
him to the electorate. The decision sent a clear signal to RAl's board members and top managers that RAl's funding under the new Renzi cabinet would be far from secure.

The extent to which political constraints continue to affect RAl's ability to take major strategic decisions is perhaps best illustrated by the recent saga of foundered attempts at reorganising RAl's newsrooms in order to reduce costs and enhance RAl's online news operations. In early 2015, RAl's then general-director Luigi Gubitosi won approval from the RAl board for a cost-saving plan to reduce the number of RAl's newsrooms from 8 to 2 , the longer-term goal being to create a single newsroom on the BBC model. The plan met with the strong opposition, both within and outside RAI. The main argument of its critics was that the effect of the reorganisation would be to undermine RAl's tradition of (external) political pluralism [safeguarded, according to this argument by a multiplicity of differently politicallyconnoted newsrooms]. With Gubitosi's tenure coming close to an end, the plan was effectively shelved. Gubitosi's successor, Antonio Campo Dall'Orto, a well-respected TV executive with significant experience in the private sector, sponsored by Renzi), also undertook to reorganise RAl's news services and in particular to strengthen RAl's digital news operation, understaffed (with a newsroom of only 15 journalists) and underperforming (ranked $30^{\text {th }}$ among the most visited portals). The plan was to create a new web portal (to be named rai24.it) staffed with 88 journalists and run by one of RAl's most well-known and trusted journalists, investigative reporter Milena Gabanelli. RAl's board rejected the plan in May 2017, which prompted Dall'Orto's immediate resignations followed by those of Gabanelli. Sources close to the Dall'Orto were quoted in Italian press as maintaining that the reasons for the dismissal of the plan by the board had been 'all political' and that RAl continued to be 'hostage to politics' - a version of facts denied by the Board members, but widely endorsed in the national press. According to journalistic accounts, the relationship between Renzi and Dall'Orto had become increasingly strained since the Dall'Orto's appointment to director-general two years earlier as a result of a series of decisions taken by Dall'Orto that had not seen with favour by Renzi (see, e.g., II Fatto Quotidiano 2017). RAl's journalists union issued a very critical press release (Usigrai, 2017a), calling it 'the final act by a general-director and a board of directors that are unsuitable for the role' and calling for 'an irresponsible management that puts its power conflicts over and above the good of RAI and public service' to leave.

With general elections scheduled to take place in March 2018, RAI was again at the centre of political rumours. Italy's daily newspaper, La Repubblica (2018) reported in early 2018 that Renzi was adamant to include in the Democratic Party's electoral manifesto a proposal to abolish the licence fee and replace it with funding from general taxation during a three-year transitional period, at the end of which RAI would then be required to rely entirely on advertising revenues (its advertising caps relaxed). The report stirred up a debate among politicians. Critical voices included leading exponents of Renzi's Democratic Party. Others stigmatised it as a blatant electoral move and pure political gameship. And RAl's journalists union issued another strongly disapproving statement (Usigrai, 2017b): 'Timely as a Swiss clock, when the electoral campaign starts, there come attacks on RAI. It's a script that has 
been repeated for years: we point out that in countries where the licence has been abolished, public service media has been greatly reduced, to the benefit of the private sector'.

\section{RAl and the digital challenge}

Similarly to its pubic and private counterparts, RAI faces serious challenges as it strives to maintain its relevance in the (expanding) online space. RAl's weak performance online stands in stark contrast to the high viewing share that its main television channels and news bulletins still command. Perhaps the most telling figure is the one relating to RAl's news website, which trails far behind its competitors. In January 2018, the rainews.it domain ranked only $33^{\text {rd }}$ in the ranking of the most popular online news sites in January 2018 (Prima Comunicazione, 2018). Its unique visitors were a mere 111,111, a figure roughly ten times lower than those of the three top news sites, namely Repubblica and Corriere della Sera (Italy's top selling newspapers) and TGCOM24 (Mediaset's news website). As this was written, RAl's general online domain (rai.it) did not even figure among the top-50 websites in Italy (according to statistics released by Alexa.com), unlike those of other domestic legacy players (both broadcasters and newspaper publishers). In her study of public service broadcasters' internet policies, Benedetta Brevini (2010: 356) argues that in Italy 'RAl's online expansion has been seriously compromised by scarce resources, management turnover and the lack of any long-term strategy'. At the time of her research, RAI NET, RAI's division for Internet activities set up in the late 1990s, was allocated just 0.2 per cent of RAl's annual budget, with priority then going to digital terrestrial television rather than online. Furthermore, RAl's online offering was characterised for its string orientation towards entrainment, as opposed news.

Two recent reports on PSM's delivery of news online by the Reuters Institute for the Study of Journalism at the University of Oxford support Brevini's earlier analysis (see Sehl et al 2016; 2018). The authors of the report identify a number of common challenges in the delivery of news online facing PSM organisations in the six countries covered in their study, including: the need to implement internal reorganisations to more effectively delivery news in an increasingly digital media environment; incorporating mobile delivery as smartphones become more and more central to how people access news; and using social media platforms as more and more news use is driven by referrals from various platforms like Facebook. RAl's approach to online news delivery is described as highly fragmented and uncoordinated, in contrast to the more centralized approach of other PSM organisations like the BBC in the UK and YLE in Finland. It was only in 2013 that rainews.it started as a unified news website with the aim of integrating content from across the organization and only in December 2015 that RAl established a new digital division to bring together the whole of RAl's digital offering. As recounted in the previous section, however, the implementation of these recent projects has hampered by internal resistance, political meddling and high turnover at top management level. 


\section{Conclusion}

RAI continues to occupy a central place within the national media landscape. In the opening paragraphs of this chapter it was highlighted how, for all its failings, RAI makes a major contribution in several key areas of provision and it is by far the main investor in local films and television programmes. And yet, political and commercial pressures have historically weakened its performance as a public service media organisation. These pressures continue unabated. This chapter has reviewed recent changes to RAl's governance and funding system under the Renzi government (20142016). It situated this latest attempt at reforming RAI both historically and in relation to contemporary economic and political conditions (notably the rise in populist politics fuelled by the economic hardships of recent years). Compared with its predecessors, Renzi certainly demonstrated a more pro-active and decisive approach to the vexed question of public service broadcasting. Linking the licence fee to electricity bills was motivated by the commendable intention of fighting evasion and ensuring its near-universal payment - and on this count the initiative can surely be judged as a success. However, the drastic reduction in the unit fee, without a serious debate accompanying this major decision, means that an opportunity was lost to bring the level of RAl's per-capita public funding more in line with those of RAl's more generously funded counterparts in continental and Northern Europe - a condition many see as necessary for raising RAl's public service profile. In the meantime, RAl's governance changes disappointed those who took Renzi at face value when pledging to keep politics out of RAI. The events surrounding the rejection of Dall'Orto's news plan by RAl's Board is illustrative of how political factors continue to have a major bearing on RAl's ability to adapt its organisational forms in order to meet the challenges that, like all its European counterparts, it is confronted with.

For the time being, RAl's position as the country's pubic service media organisation appears to be secure. In 2017, RAl's 10-year Convention with the State was renewed and, as this was written, a new service contract (2018-2022), stipulating in greater detail RAl's public service obligations, was reaching the final stage of drafting after a lengthy renewal process. Extemporaneous proposals such as Renzi's leaked plan to scrap the licence fee are unlikely to be implemented. Political analysts see them as part of the political game ahead of the forthcoming elections. They are indicative, however, of the fact that the political debate on public service media in Italy appears to be almost schizophrenic, and it is certainly poorly informed and lacking a longterm vision. Beyond political rhetoric and aspirational but ultimately empty slogans on RAl being a 'leading cultural industry' and 'a great engine of educational and cultural identity', the bare reality is that there is little genuine concern among politicians over the future of public service media in the country and no political willingness to create the enabling conditions for RAl to thrive in a digital age.

\section{References}

Agcom (2016). Relazione Annuale 2016 sull'Attività Svolta e sui Programmi di Lavoro, available at: https://www.agcom.it/relazioni-annuali 
Agcom (2017). Relazione Annuale 2017 sull'Attività Svolta e sui Programmi di Lavoro, available at: https://www.agcom.it/relazioni-annuali

Blumler, J. (1992) 'Public Service Broadcasting Before the Commercial Deluge', in Blumler, J. (ed.) Television and the Public Interest, London, Sage, pp. 7-21.

Bordignon, F. (2014) 'Matteo Renzi: A "Leftist Berlusconi” for the Italian Democratic Party?', in South European Society and Politics, vol.19, no. 1: 1-23.

Brevini, B. (2010) 'Towards PSB 2.0? Applying the PSB Ethos to Online Media in Europe: A comparative Study of PSBs' Internet policies in Spain, Italy and Britain', European Journal of Communication, vol. 25, n. 4: 348-365.

D'Arma, A. (2009). 'Broadcasting Policy in Italy's Second Republic: National Politics and European Influences', in Media, Culture and Society, vol. 31, n. 5: 769-786.

D'Arma, A. (2015) Media and Politics in Contemporary Italy: From Berlusconi to Grillo, Lanham: Lexington Books.

Hanretty, C. (2009). 'The Political Independence of Public Service Broadcasters', Thesis submitted for assessment with a view to obtaining the degree of Doctor of Political and Social Sciences of the European University Institute, Fiesole.

Hibberd, M. (2004). 'RAI under the Center-Right: Wither 50 Years of Public Service Television', in Fabbrini, S. and V. Della Sala (eds), Italian Politics: Italy between Europeanization and Domestic Politics, New York and Oxford, Berghahn, pp. 150-165.

Humphreys, P. (1996) Mass Media and Media Policy in Western Europe, Manchester, Manchester University Press.

Il Fatto Quotidiano (2017) 'Rai, bocciato il piano news: Campo dall'Orto sfiduciato dal CdA. La fine del direttore voluto (e mollato) da Renzi', 22 May, available at: https://www.ilfattoquotidiano.it/2017/05/22/rai-bocciato-il-piano-newscampo-dallorto-sfiduciato-dal-cda-la-fine-del-direttore-voluto-e-mollato-darenzi/3606029/

La Repubblica (2018) ' "Abolire il canone Rai”, la prima mossa del PD', 4 January, available at: https://rep.repubblica.it/pwa/generale/2018/01/04/news/ abolire il canone $r$ ai la prima mossa del pd-185826101/

Mancini, P. (2009) Elogio della Lottizzazione: La Via Italiana al Pluralismo, Rome-Bari, Laterza.

Mazzoleni, G. and G.E. Vigevani (2005) 'Italy', in Television across Europe: Regulation, Policy and Independence Vol. 2, Osi/Eumap, Gyoma, pp. 865-954.

Ofcom (2017) International Communications Market Report, available at: https://www.ofcom.org.uk/research-and-data/multi-sector-research/cmr/cmr2017/international

Padovani, C. (2010) 'Public Service Communication in Italy: Challenges and Opportunities', in losifidis, P. (ed.) Reinventing Public Service Communication: 
European Broadcasters and Beyond, Basingstoke, Palgrave McMillan, pp. 183196.

Padovani, C. and Tracey, M. (2003) 'Report on the Conditions of Public Service Broadcasting', in Television and the New Media vol. 4, n. 2: 131-153.

Prima Comunicazione (2018) 'Classifica e trend dei siti di news più seguiti a gennaio per audience complessiva e aggregazioni', available at:

http://www.primaonline.it/2018/03/23/269047/classifica-e-trend-dei-siti-dinews-piu-seguiti-a-gennaio-per-audience-complessiva-e-aggregazioni-taltabella/

RAI (2017) Relazione e bilancio consolidato al 31 dicembre 2016, available at: http://www.rai.it/dl/doc/2016/07/21/1469115109446_Bilancio\%20Rai\%202015 \%2030.06.2016.pdf

Richeri, G. (1990) 'Hard Times for Public Service Broadcasting: RAl in the Era of Competition', in Baranski Z. and R. Lumley (eds) Culture and Conflict in Postwar Italy, London, Macmillan, pp. 256-269.

Sehl, A., A. Cornia and R.K.Nielsen (2016) Digital News Project 2016: Public Service News and Digital Media, available at:

http://reutersinstitute.politics.ox.ac.uk/our-research/public-service-news-anddigital-media

Sehl, A., A. Cornia and R.K.Nielsen (2018) Digital News Project 2018: Public Service News and Social Media, available at:

https://reutersinstitute.politics.ox.ac.uk/our-research/public-service-news-andsocial-media

Spada, C. (2007) 'Sulle Proposte del Ministro delle Comunicazioni in Materia Televisiva', in Economia della Cultura, vol. 17, n. 1: 77-85.

Tarchi, M. (2015) 'Italy: The Promised Land of Populism?', Contemporary Italian Politics, vol. 7, n. 3: 273-285.

Usigrai (2017a) 'RAI, atto finale di dg e cda. Tutti a casa', 22 May, available at: http://www.usigrai.it/rai-atto-finale-di-dg-e-cda-tutti-a-casa/

Usigrai (2017b) 'Tutto da copione: Parte la campagna elettorale e si attacca la Rai', 5 January, available at: http://www.usigrai.it/usigrai-attacco-alla-rai-in-campagnaelettorale-un-copione-che-si-ripete-da-anni/ 